\title{
EFFECT OF CHOLINE ON THE HYPERTENSION OF RATS INDUCED BY HIGH SALT DIET
}

\author{
TATSUO KOYANAGI AND SHINICHI HAREYAMA \\ Department of Agricultural Chemistry, Faculty of Agriculture, \\ Iwate University, Morioka
}

(Received November 5, 1957)

Mild deficiency of heat-stable components of vitamin B complex was reported by Calder (1) as causing a rise in blood pressure in rats. Griffith (2) found that many animals developed hemorrhagic renal changes on a diet low in choline. Thus choline has been thought to have an intimate relation to renal hypertension. But Sobin et al. (3) have failed to make rats hypertensive in spite of long term feeding with choline-deficient rations. Later Hartroft and Best (4) found that if growing rats were subjected to choline deficiency for a short period (5 to 6 days) and were then restored to a stock ration, a certain proportion of them developed hypertension after four months. Thus choline deficiency may be the cause of hypertension under certain conditions. The present paper deals with experiments on rats in which the effect of choline supplement on the hypertension induced by Sapirstein's (5) high salt diet was investigated.

\section{EXPERIMENTAL AND RESULTS}

\section{The First Experiment.}

This was a preliminary experiment. Weanling rats of Wister strain were housed separately in metal screen-bottomed cages and were fed the basal diet consisting, in per cent, of unwashed milled rice 87 , casein 10 , dried carrot 1 ,

TABLE I

Composition of Diet

\begin{tabular}{lccc}
\multicolumn{1}{c}{ Ingredient } & Medium NaCl diet & High NaCl diet & $\begin{array}{c}\text { High NaCl plus } \\
\text { choline diet }\end{array}$ \\
Washed milled rice & $g$ & $g$ & $g$ \\
Commercial casein & 92 & 92 & 92 \\
Dried carrot & 5 & 5 & 5 \\
Calcium carbonate & 1 & 1 & 1 \\
Sodium chloride & 0.5 & 0.5 & 0.5 \\
Choline chloride & 1 & 2.5 & 2.5 \\
& 0 & 0 & 0.1
\end{tabular}

The diets were supplemented with $1 \mathrm{mg}$ of thiamine hydrochloride per $\mathrm{kg}$ of ration. 
calcium carbonate 1 , and sodium salt 1 . After 3 months on the diet the rats were divided into 3 groups and fed with 3 types of diet, viz. medium sodium chloride, high sodium chloride and high sodium chloride plus choline (Table I). As already mentioned, Sapirstein's high salt ration was used for the production of hypertension and water was restricted to the amount used to make the paste. After 4 month-feeding period the blood pressure of the animals were determined by the Williams' (6) rat tail method.

As shown in Table II, the blood pressure elevated significantly on high salt diet when compared with the medium salt diet. On the other hand, that of the high salt plus choline group did not elevate significantly but remained on the level of the medium salt salt group.

TABLE II

The Blood Pressure of Rats Fed With or Without Choline Diet

(The first expriment)

\begin{tabular}{|c|c|c|c|c|c|c|c|c|}
\hline \multicolumn{3}{|c|}{ Medium $\mathrm{NaCl}$ diet } & \multicolumn{3}{|c|}{ High $\mathrm{NaCl}$ diet } & \multicolumn{3}{|c|}{ High $\mathrm{NaCl}$ plus choline diet } \\
\hline Rat no. & $\begin{array}{l}\text { Final } \\
\text { body } \\
\text { weight }\end{array}$ & $\begin{array}{l}\text { Blood } \\
\text { pressure }\end{array}$ & $\begin{array}{l}\text { Rat } \\
\text { no. }\end{array}$ & $\begin{array}{l}\text { Final } \\
\text { body } \\
\text { weight }\end{array}$ & $\begin{array}{l}\text { Blood } \\
\text { pressure }\end{array}$ & $\begin{array}{l}\text { Rat } \\
\text { no. }\end{array}$ & $\begin{array}{l}\text { Final } \\
\text { body } \\
\text { weight }\end{array}$ & $\begin{array}{l}\text { Blood } \\
\text { pressure }\end{array}$ \\
\hline & $g$ & $m m \mathrm{Hg}$ & & $g$ & $m m \mathrm{Hg}$ & & $g$ & $m m \mathrm{Hg}$ \\
\hline 1 & 232 & 109 & 7 & 231 & 140 & 12 & 143 & 109 \\
\hline 2 & 233 & 102 & 8 & 194.5 & 138 & 13 & 196 & 113 \\
\hline 3 & 218.5 & 102 & 9 & 140 & 150 & 14 & 180 & 111 \\
\hline 4 & 205.5 & 108 & 10 & 174.5 & 150 & 15 & 170 & 109 \\
\hline 5 & 188.5 & 102 & 11 & 186 & 160 & 16 & 168.5 & 107 \\
\hline 6 & 162 & 109 & & & & 17 & 182 & 113 \\
\hline Average & & 105 & & & 147 & & & 110 \\
\hline
\end{tabular}

\section{The Second Experiment.}

The second experiment was designed to confirm the result of the first and the composition of diet was the same as the first experiment. The experimental feeding was begun after the rats had been one month on the stock diet; this was continued for 3 months.

TABLE III

The Blood Pressure of Rats Fed With or Without Choline Diet

(The second experiment)

\begin{tabular}{|c|c|c|c|c|c|c|c|c|}
\hline \multicolumn{3}{|c|}{ Medium $\mathrm{NaCl}$ diet } & \multicolumn{3}{|c|}{$\mathrm{High} \mathrm{NaCl}$ diet } & \multicolumn{3}{|c|}{ High $\mathrm{NaCl}$ plus choline diet } \\
\hline Rat no. & $\begin{array}{l}\text { Final } \\
\text { body } \\
\text { weight }\end{array}$ & $\begin{array}{l}\text { Blood } \\
\text { pressure }\end{array}$ & $\begin{array}{l}\text { Rat } \\
\text { no. }\end{array}$ & $\begin{array}{l}\text { Final } \\
\text { body } \\
\text { weight }\end{array}$ & $\begin{array}{l}\text { Blood } \\
\text { pressure }\end{array}$ & $\begin{array}{l}\text { Rat } \\
\text { no. }\end{array}$ & $\begin{array}{l}\text { Final } \\
\text { body } \\
\text { weight }\end{array}$ & $\begin{array}{l}\text { Blood } \\
\text { pressure }\end{array}$ \\
\hline & $g$ & $m m \mathrm{Hg}$ & & $g$ & $m m \mathrm{Hg}$ & & g & $\mathrm{mm} \mathrm{Hg}$ \\
\hline Average & $\begin{array}{l}239.5 \\
188.5\end{array}$ & $\begin{array}{l}95 \\
94\end{array}$ & $\begin{array}{r}1 \\
21 \\
2 \\
40 \\
17 \\
3\end{array}$ & $\begin{array}{l}248 \\
250 \\
190 \\
174.5 \\
188.5 \\
203.5\end{array}$ & $\begin{array}{r}125 \\
105 \\
132 \\
122 \\
97 \\
120 \\
118\end{array}$ & $\begin{array}{r}14 \\
16 \\
28 \\
7 \\
42\end{array}$ & $\begin{array}{l}246 \\
218.3 \\
198.5 \\
161.5 \\
193.3\end{array}$ & $\begin{array}{r}112 \\
93 \\
101 \\
105 \\
91 \\
\\
\mathbf{1 0 0 . 4}\end{array}$ \\
\hline
\end{tabular}


The result of the measurement of blood pressure (Table III) agreed with the result of the first experiment. In other words, the addition of choline to the high salt diet had prevented the elevation of blood pressure.

\section{The Third Experiment.}

In the diet of the third experiment the casein was substituted with the same amount of defatted soybean meal. The rats were kept 3 months on the stock diet and then transferred to the experiment diet. After 3 month-feeding the blood pressure was measured; the animals were decapitated; succinoxidase activity of the liver and kidney, and cholesterol content in the serum and liver were determined (Table IV).

The result of the blood presdure measurement showed that the high salt condition elevated the blood pressure more severely on the soybean diet than on the casein diet. A supplement of choline to the diet could prevent the

TABLE IV

The Blood Pressure and Succinoxidase of Liver and Kidney, Cholesterol of Serum and Liver of Rats Fed With or Without Choline Diet

(The third experiment)

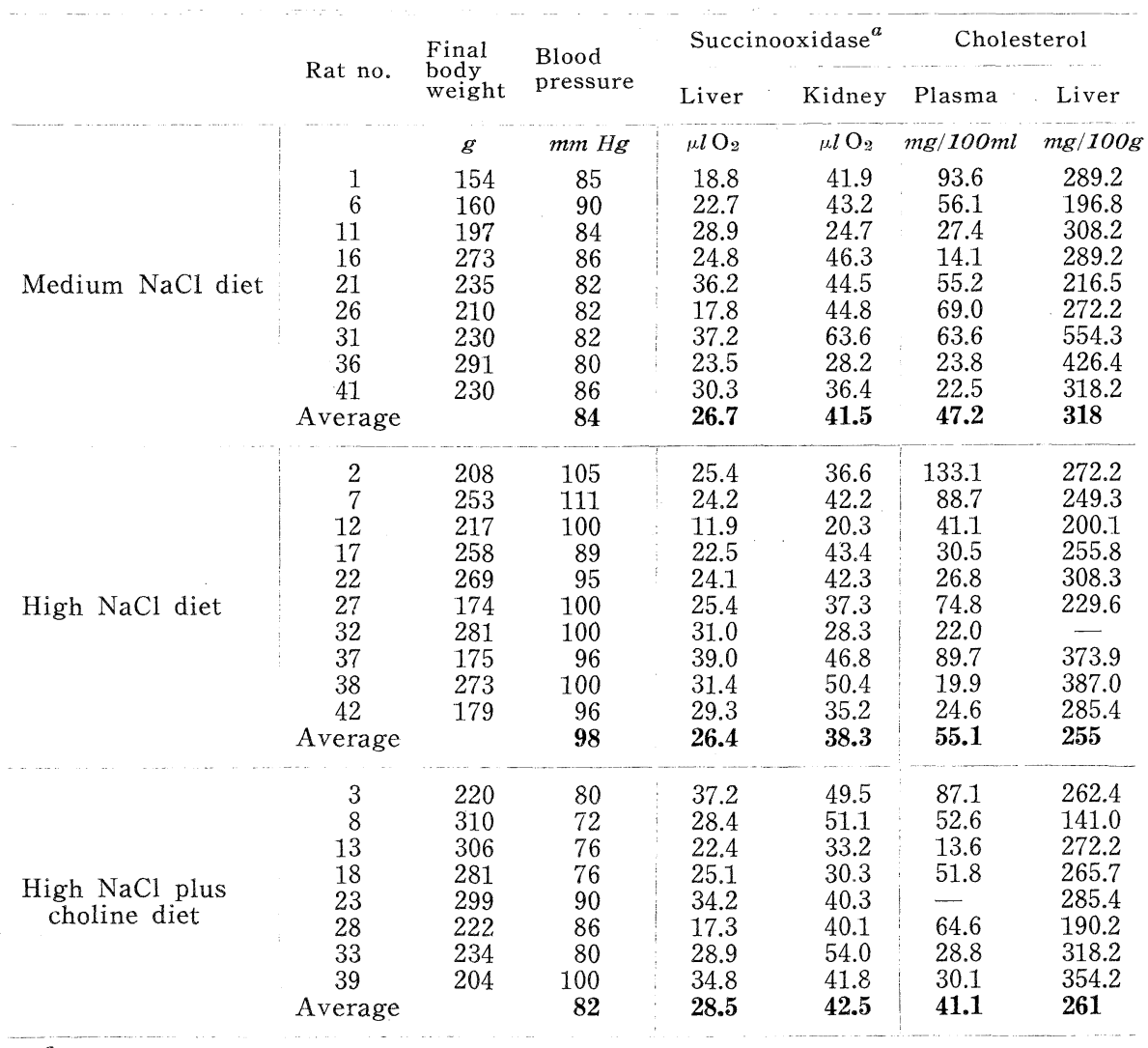

a $\mu_{1} \mathrm{O}_{2}$ uptake per $40 \mathrm{mg}$ of fresh material in $10 \mathrm{~min}$. 
elevation of blood pressure as was the case with the preceding experiments. No difference in the succinoxidase activity in the liver and kidney, cholesterol of serum and liver of these rats was observed.

\section{DISCUSSION}

The cause of the failure of Sobin et al. to effect hypertension in the rats on the ration deficient of choline in spite of long term feeding must have been due to the too severe depletion of the vitamin, a depletion which would not even allow subnormal rat growth. Our diet consisted of washed rice and casein or soybean meal which still contained some choline so that the animals were not in a state of severe depletion. Using such a basal diet, we could prevent the elevation of blood pressure induced by high salt diet by adding choline to the diet.

Guggenheim (7) reported that the vasopressin-inactivating ability of rat liver was reduced by choline deficiency. This fact seems to have some relation to our findings.

\section{SUMMARY}

The addition of choline to the diet could prevent the elevation of blood pressure induced by high salt diet.

\section{REFERENCES}

1. Calder, R. M., J. Exp. Med. 76, 1 (1942).

2. Griffith, W. H., J. Biol. Chem. 131, 567 (1939).

3. Sobin, S. S. and Landis, E. M., Am. J. Physiol. 148, 557 (1947).

4. Hartroft, W. S. and Best, C. H., Brit. Med. J. 1, 423 (1949).

5. Sapirstein, L. A., Brandt, W. L. and Drury, D. R., Proc. Soc. Exptl. Biol. Med. 73, $82(1950)$.

6. Williams, J. R., J. Clin. Invest. 18, 373 (1939).

7. Guggenheim, K. J., and Diamant, E. J., J. Nutrition 57, 249 (1955). 